\title{
PERBEDAAN PENGETAHUAN, SIKAP DAN KETERAMPILAN SEBELUM DAN SESUDAH PEMBENTUKAN SERDADU JENTIK DI SD NEGERI DALAM PENCEGAHAN DEMAM BERDARAH DENGUE
}

\author{
Wella Sahri Ramadhani, Wijayantono, Darwel \\ (Politeknik Kesehatan Kemenkes Padang)
}

\begin{abstract}
This research is quantitative and carried out using the research design of one group Pre test posttest. The research sample was 4th grade students who became small doctors in 7 elementary schools in Surau Gadang Village. Implementation of research November December 2018. Primary data obtained directly from filling out the research questionnaire by sample. Based on these results it can be concluded that there are differences in knowledge, attitudes and skills before and after the formation of larvae soldiers in Public Elementary Schools in the Prevention of DHF Cases in Surau Gadang Sub-District, Nanggalo District, Padang City in 2018. It is expected that the school will complete facilities such as flashlights. School Health Business (SHB)Teachers supervise larva soldiers once a week. For DHF program holders the Health center can continue the DHF counseling activities to schools once a month and provide leaflets and posters about DHF.
\end{abstract}

Keyword : Soldiers Flies,DHF, SHB, Flashlights, Counseling

\begin{abstract}
Abstrak
Penelitian ini bersifat kuantitatif dan dilaksanakan dengan menggunakan desain penelitian one group pre test post test. Sampel penelitiannya adalah siswa kelas IV yang menjadi dokter kecil di 7 SDN Kelurahan Surau Gadang. Pelaksanaan penelitian bulan November Desember 2018. Data primer diperoleh langsung dari pengisian angket penelitian oleh sampel. Pada penelitian ini didapatkan bahwa terjadi peningkatan rata-rata pengetahuan, sikap Berdasarkan hasil tersebut dapat disimpulkan ada perbedaan pengetahuan, sikap dan keterampilan sebelum dan sesudah dilakukan pembentukan serdadu jentik di Sekolah Dasar Negeri dalam pencegahan kasus Demam Berdarah Dengue pada Kelurahan Surau Gadang Kecamatan Nanggalo Kota Padang tahun 2018. Diharapkan pihak sekolah melengkapi sarana seperti senter. Guru UKS melakukan pengawasan serdadu jentik 1 kali seminggu. Untuk pemegang program DBD Puskesmas dapat melanjutkan kegiatan penyuluhan DBD ke sekolah 1 kali sebulan dan pemberian leaflet serta poster mengenai DBD.
\end{abstract}

\section{Kata Kunci : Serdadu Jentik, DBD, UKS, Senter,Penyuluhan}

\section{PENDAHULUAN}

Demam Berdarah Dengue (DBD) merupakan salah satu penyakit menular yang menjadi masalah kesehatan di dunia, terutama Negara berkembang. Di Indonesia masalah DBD muncul pertama tahun 1968 di Surabaya. Belakangan ini, masalah DBD telah menjadi masalah klasik yang kejadiannya hampir dipastikan muncul setiap tahun terutama pada awal musim penghujan.

Dalam Program Pembangunan Nasional (Propenas) tertulis bahwa indikator penyakit DBD sebesar 20 per 100.000 penduduk untuk daerah endemis pada tahun 2010 . Kondisi ini 
sulit dicapai apabila tidak ditangani secara serius. Pemberantasan demam berdarah dengue ini sebenarnya cukup mudah bila ada kerja sama yang baik antara pemerintah dan masyarakat dalam kegiatan Pemberantasan Sarang Nyamuk (PSN). Upaya ini merupakan investasi jangka panjang, tetapi dapat menjamin kesinambungan dan keberhasilan program pemberantasan DBD.

Faktor-faktor yang berperan terhadap peningkatan kasus DBD antara lain kepadatan vektor, kepadatan penduduk yang terus meningkat sejalan dengan pembangunan kawasan pemukiman, urbanisasi yang tidak terkendali, meningkatnya sarana transportasi (darat, laut dan udara), perilaku masyarakat yang kurang sadar terhadap kebersihan lingkungan, serta perubahan iklim (climate change). Pengendalian penyakit Deman Berdarah Dengue (DBD) telah diatur dalam Keputusan Menteri Kesehatan Nomor 581/MENKES/SK/VII/1992 tentang Pemberantasan Penyakit Demam Berdarah dan Keputusan Menteri Kesehatan nomor 92 tahun 1994 tentang perubahan atas lampiran Keputusan Menteri Kesehatan Nomor 581/MENKES/SK/1992, dimana menitikberatkan pada upaya pencegahan dengan gerakan pemberantasan sarang nyamuk (PSN) selain penatalaksanaan penderita DBD dengan memperkuat kapasitas pelayanan kesehatan dan sumber daya, memperkuat surveilans epidemiologi dan optimalisasi kewaspadaan dini terhadap Kejadian Luar Biasa (KLB) DBD. Manajemen pengendalian vektor secara umum diatur dalam Peraturan Menteri Kesehatan Republik Indonesia Nomor 374/MENKES/PER/III/2010 tentang Pengendalian Vektor.

Mengingat obat dan untuk mencegah virus Dengue hingga saat ini belum tersedia, maka cara utama yang dapat dilakukan sampai saat ini adalah dengan pengendalian vektor penular (Aedes aegypti). Pengendalian vektor ini dapat dilakukan dengan pelaksanaan kegiatan PSN 3M Plus

Upaya pemberdayaan masyarakat dengan melaksanakan kegiatan PSN 3M Plus (menguras, menutup tempat penampungan air dan mendaur-ulang/ memanfaat kembali barang-barang bekas) serta ditambah (Plus) seperti : menaburkan larvasida pembasmi jentik, memelihara ikan pemakan jentik, mengganti air dalam pot/vas bunga dan lain-lain. Upaya ini melibatkan lintas program dan lintas sektor terkait melalui wadah Kelompok Kerja Operasional Demam Berdarah Dengue (Pokjanal DBD) dan kegiatan Juru Pemantau Jentik (Jumantik). Oleh karena itu peran keluarga perlu terus ditingkatkan untuk melakukan pemantauan, pemeriksaan dan pemberantasan jentik. Konsep inilah yang disebut dengan "Jumantik Rumah Tangga atau Satu Rumah Satu Jumantik".

Menurut Shepard et al (2013) DBD merupakan penyakit yang menular melalui gigitan nyamuk Aedes aegypti, yang menjadi masalah kesehatan masyarakat akibat buruknya kondisi lingkungan dan berdampak serius karena tingginya endemisitas penyakit ini membuat Indonesia menjadi Negara dengan kasus DBD tertinggi di Asia Tenggara tahun 2013. 
Provinsi Sumatera Barat merupakan salah satu provinsi di Indonesia dengan kasus DBD yang tinggi. Incidence Rate (IR) DBD Provinsi Sumatera Barat pada tahun 2017 adalah 46,42 per 100.000 penduduk dengan Case Fatality Rate (CFR) sebesar 0,28\%. Sedangkan target IR DBD nasional adalah < 49 per 100.000 penduduk dan target CFR nasional maka IR DBD sumbar memang belum melebihi target namunnya masih sangat tinggi diatas IR Indonesia yang hanya 26.42 per 100.000 penduduk.

Kota Padang merupakan daerah yang endemis terhadap penyakit DBD karena dari 104 kelurahan semuanya sudah ada kasus DBD. Berdasarkan data yang dikumpulkan seluruh rumah sakit Kota Padang, tahun 2015 kasus DBD dan kasus kematian terjadi peningkatan dibandingkan tahun 2014, dimana pada tahun 2014 sebanyak 666 kasus dengan 6 kasus kematian, sedangkan tahun 2015 sebanyak 998 kasus dengan 8 kasus kematian. Untuk tahun 2016 berjumlah 911 kasus dengan angka kematian 11 orang, CFR DBD adalah 1,2\%. Untuk tahun 2017 jumlah kasus DBD sebanyak 608 kasus dengan angka kematian 4 orang, berarti CFR DBD adalah 0,66\%.

Puskesmas Nanggalo adalah salah satu puskesmas yang endemis terhadap kasus DBD. Tercatat selama tahun 2017 Puskesmas Nanggalo menyumbang sebanyak 31 kasus. Jumlah ini sudah menurun dari angka kasus pada tahun 2016 dengan 43 kasus. Akan tetapi di tahun 2017 terdapat 1 kasus kematian. Dari 31 kasus DBD yang terjadi di Wilayah Kerja Puskesmas Nanggalo, 35,5 \% terjadi pada usia anak sekolah terutama anak SD yaitu usia 6-12 th.

Dalam hal pengendalian penyakit Demam Berdarah Dengue (DBD) ini, Kota Padang telah mengeluarkan Peraturan Walikota Padang Nomor 26 Tahun 2017 Tentang Pengendalian Penyakit DBD sebagai upaya bersama Dinas Kesehatan dalam memerangi penyakit DBD ini. Adapun ruang lingkupnya adalah pencegahan, pencegahan, penanganan penderita DBD dan pencegahan KLB. Di dalam pencegahan disebutkan adalah kegiatan Pemantauan Jentik Berkala (PJB) salah satunya adalah kegiatan pembentukan tim serdadu jentik di sekolah-sekolah. Upaya ini juga telah dicanangkan di Puskesmas Nanggalo untuk membentuk tim serdadu jentik di SD Negeri Kelurahan Surau Gadang. Kelurahan Surau Gadang dipilih dikarenakan kasus paling tinggi berada disana.

Jumantik anak sekolah (serdadu jentik) adalah penguatan peranan anak sekolah dari berbagai jenjang pendidikan dasar yang telah dibina dan dilatih sebagai Juru Pemantau Jentik (Jumantik) di sekolahnya. Pembentukan dan pelaksanaan serdadu jentik dimaksudkan untuk ikut serta mendukung program pemerintah dalam upaya Pemberantasan Sarang Nyamuk (PSN) penular demam berdarah dengue serta sebagai salah satu upaya pembinaan Perilaku Hidup Bersih dan Sehat (PHBS) sejak usia dini. 
Disetiap sekolah di wilayah kerja puskesmas Kota Padang telah dibentuk tim serdadu jentik termasuk di Wilayah Kerja Puskesmas Nanggalo terutama Kelurahan Surau Gadang. Keikutsertaan tim serdadu jentik juga diharapkan dapat meningkatkan Angka Bebas Jentik (ABJ) di SD karena ABJ di SD yang ada di wilayah kerja Puskesmas Nanggalo berdasarkan data laporan DBD hanya $65 \%$, masih jauh dari target nasional yaitu $\geq 95 \%$.

Berdasarkan survey awal dan tingginya angka kejadian DBD pada anak SD di Puskesmas Nanggalo, serta rendahnya ABJ di SD Wilayah Kerja Puskesmas Nanggalo khususnya Kelurahan Surau Gadang, maka peneliti ingin mengetahui Perbedaan Pengetahuan, Sikap dan Keterampilan Sebelum dan Sesudah Pembentukan Serdadu Jentik di Sekolah Dasar Negeri dalam Pencegahan Kasus Demam Berdarah Dengue pada Kelurahan Surau Gadang Kecamatan Nanggalo Kota Padang Tahun 2018.

Tujuan Umum Penelitian ini adalah Mengetahui Perbedaan Pengetahuan, Sikap dan Keterampilan Sebelum dan Sesudah Pembentukan Serdadu Jentik di Sekolah Dasar Negeri dalam Pencegahan Kasus Demam Berdarah Dengue pada Kelurahan Surau Gadang Kecamatan Nanggalo Kota Padang Tahun 2018.

\section{METODE PENELITIAN}

Penelitian ini bersifat kuantitatif dan dilaksanakan dengan menggunakan desain penelitian one group pre test post test. Populasi adalah 7 SDN yang berada di Kelurahan Surau Gadang dan Siswa yang menjadi dokter kecil. Sampel penelitiannya adalah siswa kelas IV yang menjadi dokter kecil di 7 SDN Kelurahan Surau Gadang yang berjumlah 56 orang. Pelaksanaan penelitian bulan November - Desember 2018. Data primer diperoleh langsung dari pengisian angket penelitian oleh sampel.

\section{HASIL PENELITIAN}

\section{Analisa Univariat}

Tabel. 1 Gambaran Pengetahuan Siswa Sebelum dan Sesudah Pembentukan Serdadu Jentik Di Sekolah Dasar Negeri Kelurahan Surau Gadang Kecamatan Nanggalo Kota Padang Tahun 2018

\begin{tabular}{cccccc}
\hline No & Variabel & Mean & SD & Min-Max & N \\
\hline 1 & Pre Test & 8.36 & 1.6 & $5-11$ & 56 \\
2 & Post Test & 11.79 & 0.967 & $9-13$ & 56 \\
\hline
\end{tabular}

Dari tabel 1 diketahui bahwa rata-rata pengetahuan siswa pada pre test adalah 8.36 sedangkan rata-rata pengetahuan siswa pada saat post test adalah 11.79. 
Tabel. 2 Gambaran Sikap Siswa Sebelum dan Sesudah Pembentukan Serdadu Jentik Di Sekolah Dasar Negeri Kelurahan Surau Gadang Kecamatan Nanggalo Kota Padang Tahun 2018

\begin{tabular}{cccccc}
\hline No & Variabel & Mean & SD & Min-Max & N \\
\hline 1 & Pre Test & 33.52 & 3.638 & $24-40$ & 56 \\
2 & Post Test & 37.71 & 1.713 & $34-40$ & 56 \\
\hline
\end{tabular}

Dari tabel 2 diketahui bahwa rata-rata sikap siswa pada pre test adalah 33.52 sedangkan rata-rata sikap siswa pada saat post test adalah 37.71

Tabel. 3 Gambaran Keterampilan Siswa Sebelum dan Sesudah Pembentukan Serdadu Jentik Di Sekolah Dasar Negeri Kelurahan Surau Gadang Kecamatan Nanggalo Kota Padang Tahun 2018

\begin{tabular}{cccccc}
\hline No & Variabel & Mean & SD & Min-Max & N \\
\hline 1 & Pre Test & 1.61 & 0.731 & $0-3$ & 56 \\
2 & Post Test & 2.63 & 0.489 & $2-3$ & 56 \\
\hline
\end{tabular}

Dari tabel 3 diketahui bahwa rata-rata keterampilan siswa pada pre test adalah 1.61 sedangkan rata-rata keterampilan siswa pada saat post test adalah 2.63.

\section{Analisa Bivariat}

Tabel. 4 Hasil Uji Paired Sampel T-Test skor pengetahuan, sikap dan keterampilan siswa sebelum dan sesudah kegiatan pembentukan serdadu jentik di Sekolah Dasar Negeri tahun 2018

\begin{tabular}{cllccc}
\hline No & \multicolumn{2}{c}{ Variabel } & Mean & N & p Value \\
1 & Pengetahuan & Pre Test & 8.36 & 56 & 0.0001 \\
& & Post Test & 11.79 & 56 & \\
2 & Sikap & Pre Test & 33.52 & 56 & 0.0001 \\
& & Post Test & 37.71 & 56 & \\
3 & \multirow{2}{*}{ Keterampilan } & Pre Test & 1.61 & 56 & \multirow{2}{*}{0.0001} \\
& & Post Test & 2.63 & 56 & \\
\hline
\end{tabular}

Dari tabel 4 diketahui bahwa berdasarkan uji statistik Paired Sampel T-Test baik pengetahuan, sikap dan keterampilan diperoleh $p$ value sebesar 0.0001 . Hal ini menunjukan ada perbedaan pengetahuan, sikap dan keterampilan sebelum dan sesudah dilakukan pembentukan serdadu jentik di Sekolah Dasar Negeri dalam Pencegahan Kasus Demam Berdarah Dengue pada Kelurahan Surau Gadang Kecamatan Nanggalo Kota Padang tahun 2018 dengan tingkat kepercayaan $95 \%$. 
Tabel. 5 Angka Bebas Jentik (ABJ) Sebelum dan Sesudah Pembentukan Serdadu Jentik Di Sekolah Dasar Negeri Kelurahan Surau Gadang Kecamatan Nanggalo Kota Padang Tahun 2018

\begin{tabular}{|c|c|c|c|}
\hline \multirow{2}{*}{ No } & \multirow{2}{*}{ Nama Sekolah } & \multicolumn{2}{|c|}{ Keberadaan Jentik } \\
\hline & & Pre test & Post test \\
\hline 1 & SDN 09 SG & + & - \\
\hline 2 & SDN 15 SG & - & - \\
\hline 3 & SDN 10 SG & + & - \\
\hline 4 & SDN 13 SG & + & - \\
\hline 5 & SDN 05 SG & + & - \\
\hline 6 & SDN 16 SG & + & - \\
\hline \multirow[t]{2}{*}{7} & SDN 08 SG & - & - \\
\hline & $\mathrm{ABJ}$ & $28.6 \%$ & $100 \%$ \\
\hline
\end{tabular}

Dari tabel diatas diketahui bahwa ABJ sekolah pada pre test adalah $28.6 \%$ sedangkan ABJ sekolah pada saat post test adalah $100 \%$.

\section{PEMBAHASAN}

Hasil penelitian menunjukan bahwa terjadi kenaikan rata-rata pengetahuan pada post test sebesar 11,79 dari rata-rata pre test hanya 8,36. Ada beberapa pertanyaan pengetahuan yang mengalami kenaikan yang signifikan antara pre test dan post test diantaranya penyebab DBD dari 53,6\% menjadi $91,1 \%$, waktu menggigit dari 8,9 \% menjadi $80,4 \%$, ciri jentik DBD dari $25 \%$ menjadi $76,8 \%$, 3M Plus dari $53,6 \%$ menjadi $83,9 \%$ dan PSN dari 39,3\% menjadi $85,7 \%$.

Hasil penelitian ini sesuai dengan penelitian yang dilakukan oleh Ainia Nurul Aqida (2017) yang menyatakan bahwa terdapat peningkatan pengetahuan siswa pemantau jentik setelah dilakukan pelatihan di sekolah dasar kecamatan pamulang. Jadi dapat disimpulkan bahwa terdapat peningkatan pengetahuan antara sebelum dan sesudah pembentukan serdadu jentik.

Peningkatan pengetahuan pada serdadu jentik ini juga dikarenakan pembentukan merupakan suatu bentuk pendidikan kesehatan yang dapat menyalurkan informasi terkait penyakit DBD kepada serdadu jentik sehingga dapat meningkatkan pengetahuan mereka. Hal ini sesuai dengan teori yang menyatakan bahwa promosi kesehatan merupakan salah satu usaha yang dapat dilakukan untuk meningkatkan pengetahuan seseorang. ${ }^{(27)}$

Pengetahuan siswa mengenai DBD dan vektor penyebabnya serta faktor yang mempengaruhi keberadaan jentik nyamuk Aedes aegypti sangat diperlukan untuk mencegah terjadinya penularan penyakit DBD serta menekan perkembangan dan pertumbuhan jentik nyamuk Aedes aegypti. ${ }^{(32)}$

Kegiatan serdadu jentik ini juga harus selalu dipantau oleh guru UKS dan petugas pemegang program DBD Puskesmas Nanggalo yaitu berupa penyuluhan dan pemberian 
leaflet serta poster mengenai DBD. Hal ini dilakukan agar siswa dan guru terus terpapar dengan informasi DBD yang terbaru, sehingga tim serdadu jentik ini lebih maksimal dalam mejalankan tugasnya.

\section{Perbedaan sikap siswa sebelum dan sesudah pembentukan serdadu jentik}

Dari hasil penelitian diketahui bahwa terdapat kenaikan rata-rata sikap siswa antara pre test dan post test yaitu 33,52 menjadi 37,71. Ada beberapa pernyataan sikap yang mengalami kenaikan yang signifikan antara pre test dan post test diantaranya melakukan pemeriksaan jentik mandiri pada pre test terdistribusi pada jawaban paling baik 39,3\% sedangkan pada post test menjadi $57,1 \%$, bak yang tidak digunakan tidak perlu ditutup pada pre test jawaban yang paling baik hanya $28,6 \%$ sedangkan pada post test menjadi $62,5 \%$ dan memakai lotion ke sekolah pada pre test jawaban yang paling baik 39,3\% menjadi $76,8 \%$.

Hasil penelitian ini sesuai dengan penelitian yang dilakukan oleh Sugiono (2012) yang menyatakan bahwa terdapat peningkatan sikap siswa SDN Wirogunan Kartasura setelah adanya pembentukan pencegahan DBD. Dalam penelitian lain juga disebutkan terdapat peningkatan sikap setelah adanya penerapan promosi kesehatan dalam pencegahan penanggulangan penyakit DBD di Kota Pekanbaru (Suyanto et al., 2009). Jadi dapat disimpulkan bahwa terdapat peningkatan sikap antara sebelum dan sesudah pembentukan Serdadu jentik

Adanya peningkatan sikap dapat dikarenakan informasi yang disampaikan saat pembentukan dapat meningkatkan pengetahuan pada serdadu jentik. Berdasarkan teori yang dikemukakan oleh Notoatmodjo (2012) diketahui bahwa pengetahuan memiliki peranan yang sangat penting dalam penentuan sikap seseorang. Sebagian besar serdadu jentik telah mengetahui bahaya dan cara penanggulangan DBD sehingga hal ini membuat sikap serdadu jentik dalam pelaksanaan PSN DBD di sekolah juga meningkat

Dari pemaparan tersebut, jelas terlihat bahwa sikap tidak muncul secara tiba-tiba. Sikap muncul setelah adanya suatu informasi yang diterima oleh serdadu jentik. Sikap merupakan kesiapan atau kesediaan untuk bertindak dan bukan merupakan pelaksanaan suatu motif, namun sikap belum termasuk tindakan.

Sama halnya dengan pengetahuan, sikap siswa juga perlu diamati dengan seksama apakah sudah mencerminkan sebagai serdadu jentik atau tidak. Hal ini tentu harus ada keterpaparan siswa lebih sering dengan sarana (leaflet dan poster) mengenai DBD. Oleh karena itu, petugas pemegang program DBD harus merencanakan secara berkala (misalnya 1 kali dalam sebulan) untuk memantau dan memberikan penyuluhan kepada siswa serdadu jentik. 


\section{Perbedaan keterampilan siswa sebelum dan sesudah pembentukan serdadu jentik}

Hasil penelitian menunjukan bahwa terjadi kenaikan rata-rata keterampilan pada post test sebesar 2,63 dari rata-rata pre test hanya 1,61. Pada saat pre test pencatatan jenis kontainer yang jawaban benar hanya $37,5 \%$ sedangkan pada post test menjadi $89,3 \%$ dan pencatatan jumlah jentik yang jawaban benar 33,9\% sedangkan pada post test menjadi $73,2 \%$. Hal ini mungkin saja terjadi karena sebelum pembentukan serdadu jentik siswa menyamakan jumlah jenis kontainer dengan jumlah jentik pada kontainer, tapi setelah dilakukan pembentukan serdadu jentik menunjukkan adanya peningkatan keterampilan pemantauan jentik pada serdadu jentik. Peningkatan keterampilan tersebut dapat dikarenakan adanya peningkatan pengetahuan dan sikap serdadu jentik setelah dilaksanakannya pembentukan serdadu jentik.

Hasil penelitian ini sesuai dengan penelitian yang dilakukan oleh Ainia Nurul Aqida (2017) yang menyatakan bahwa terdapat peningkatan keterampilan siswa pemantau jentik setelah dilakukan pelatihan di sekolah dasar kecamatan pamulang. Jadi dapat disimpulkan bahwa terdapat peningkatan keterampilan antara sebelum dan sesudah pembentukan Serdadu jentik.

Pada saat pelaksanaan observasi keterampilan ternyata sekolah tidak ada senter untuk sarana penunjang dalam melihat jentik yang berada di tempat yang gelap. Hal ini tentu akan menjadi penghambat pelaksanaan serdadu jentik di waktu yang akan datang. Sehingga sangat disarankan kepada pihak sekolah untuk menyediakan senter untuk tim serdadu jentik sebanyak 8 buah per sekolah sesuai dengan jumlah siswa yang menajdi serdadu jentik.

\section{Perbedaan angka bebas jentik sekolah sebelum dan sesudah pembentukan serdadu jentik}

Peningkatan pengetahuan, sikap dan keterampilan serdadu jentik akan berbanding lurus dengan peningkatan angka bebas jentik sekolah yang dilakukan penelitian. Hal ini terlihat pada hasil ABJ pada saat pre test hanya sebesar $28,6 \%$ sedangkan pada saat post test menjadi $100 \%$.

Hasil penelitian ini sesuai dengan penelitian yang dilakukan oleh Rizqi Mubarokah (2013) yang menyatakan bahwa ada perbedaan Angka Bebas Jentik Demam Berdarah Dengue (ABJ DBD) antara sebelum dan sesudah penggerakan Juru Pemantau Jentik (Jumantik) di RW I Kelurahan Danyang Kecamatan Purwodadi Kabupaten Grobogan. Sehingga dapat disimpulkan bahwa penggerakan Juru Pemantau Jentik (Jumantik) dapat meningkatkan Angka Bebas Jentik Demam Berdarah Dengue (ABJ DBD) di RW I Kelurahan Danyang Kecamatan Purwodadi Kabupaten Grobogan.

Pemeriksaan jentik merupakan pemeriksaan tempat-tempat perkembangbiakan nyamuk Aedes aegypti yang dilakukan secara teratur oleh petugas kesehatan atau kader 
atau petugas pemantau jentik (Jumantik). Tujuan pemeriksaan jentik adalah untuk melakukan pemeriksaan jentik nyamuk penular DBD dan memotivasi keluarga dan masyarakat dalam melaksanakan PSN DBD. Dengan kunjungan yang berulang-ulang disertai penyuluhan diharapkan masyarakat dapat melakukan PSN DBD secara teratur dan terus-menerus.

Dalam hal ini peneliti juga mengharapkan kepada petugas pemegang program DBD di Puskesmas Nanggalo melakukan monitoring dan evaluasi kegiatan serdadu jentik dengan memeriksa buku rapor serdadu jentik yang diisi oleh siswa. Monev ini dilakukan setiap bulan terhadap 7 sekolah agar selalu terpantau jentik sekolah secara berkala dan mengurangi penularan kasus DBD di sekolah.

\section{SIMPULAN DAN SARAN}

\section{Kesimpulan}

1. Terjadi peningkatan rata-rata pengetahuan siswa pada pre test adalah 8.36 sedangkan pada saat post test adalah 11.79. Pada variabel sikap juga terjadi peningkatan rata-rata pada pre test adalah 33.52 sedangkan pada saat post test adalah 37.71 . Kemudian pada variabel keterampilan terjadi peningkatan rata-rata pada pre test adalah 1.61 sedangkan pada saat post test adalah 2.63.

2. Terdapat ada perbedaan pengetahuan, sikap dan keterampilan sebelum dan sesudah dilakukan pembentukan serdadu jentik di Sekolah Dasar Negeri Dalam Pencegahan Kasus Demam Berdarah Dengue pada Kelurahan Surau Gadang Kecamatan Nanggalo Kota Padang tahun 2018. Hasil uji statistik Paired Sampel T-Test baik pengetahuan, sikap dan keterampilan diperoleh $p$ value sebesar 0.0001 .

3. Terjadi peningkatan Angka Bebas Jentik (ABJ) sekolah pada pre test adalah $28.6 \%$ sedangkan pada saat post test adalah $100 \%$.

\section{Saran}

1. Bagi Sekolah

Diharapkan pihak sekolah melengkapi sarana untuk kegiatan serdadu jentik sekolah seperti senter. Untuk guru UKS agar lebih fokus kepada pengawasan serdadu jentik yang dilakukan 1 kali dalam seminggu sehingga menciptakan sekolah yang bebas jentik.

2. Bagi Puskesmas

Diharapkan bagi puskesmas terutama petugas pemegang program DBD dapat melanjutkan kegiatan penyuluhan tentang DBD ke sekolah 1 kali dalam sebulan, pemeriksaan buku rapor serdadu jentik yang telah diberikan, pemberian leaflet serta poster mengenai DBD kepada pihak sekolah. 


\section{DAFTAR PUSTAKA}

Aqida, Ainia Nurul. 2017. Pengaruh Pelatihan Wawantik Terhadap Pengetahuan, Sikap dan Keterampilannya di Sekolah Dasar Kecamatan Pamulang Tahun 2017. Skripsi. Fakultas Kedokteran dan IImu Kesehatan UIN Syarif Hidayatullah : Jakarta

Dinas Kesehatan Provinsi Sumbar, 2017. Laporan Tahunan Dinas Kesehatan Provinsi Sumbar Tahun 2017. Padang : Dinkes Prov. Sumbar

Dinas Kesehatan Kota Padang, 2017. Laporan Tahunan Dinas Kesehatan Kota Padang Tahun 2017. Padang : DKK Padang

Kemenkes RI. 2016. Petunjuk Teknis Implementasi PSN 3M-Plus dengan Gerakan 1 Rumah 1 Jumantik. Jakarta : Dirjen P2PL Kementerian Kesehatan RI

Puskesmas Nanggalo. 2017. Data DBD Puskesmas Nanggalo. Padang : Puskesmas Nanggalo

Kemenkes RI. 2013. Buku Saku Pengendalian Demam Berdarah Dengue untuk Pengelola Program DBD Puskesmas. Jakarta : Dirjen P2PL Kementerian Kesehatan RI

Kemenkes RI, 2014. Petunjuk Teknis Jumantik - PSN Anak Sekolah. Jakarta: Dirjen P2PL Kementerian Kesehatan RI

Notoatmodjo, S. 2012. Promosi Kesehatan dan Perilaku Kesehatan. Jakarta: Rineka Cipta

Notoatmodjo, S., 2014. Kesehatan Masyarakat IImu dan Seni. Jakarta : Rineka Cipta

Notoatmodjo, S., 2012. Metode Penelitian Kesehatan. Jakarta: Rineka Cipta

Mubarokah, Rizqi. 2013. Upaya Peningkatan Angka Bebas Jentik Demam Berdarah Dengue (ABJ-DBD) Melalui Penggerakan Juru Pemantau Jentik (Jumantik) Di Rw I Kelurahan Danyang Kecamatan Purwodadi Kabupaten Grobogan Tahun 2012. Skripsi. Jurusan IImu Kesehatan Masyarakat Fakultas IImu Keolahragaan Universitas Negeri Semarang : Semarang

Direktorat Jenderal Pengendalian Penyakit dan Penyehatan Lingkungan. 2010, Pencegahan dan Pemberantasan Demam Berdarah Dengue di Indonesia, Departemen Kesehatan Republik Indonesia, Jakarta 